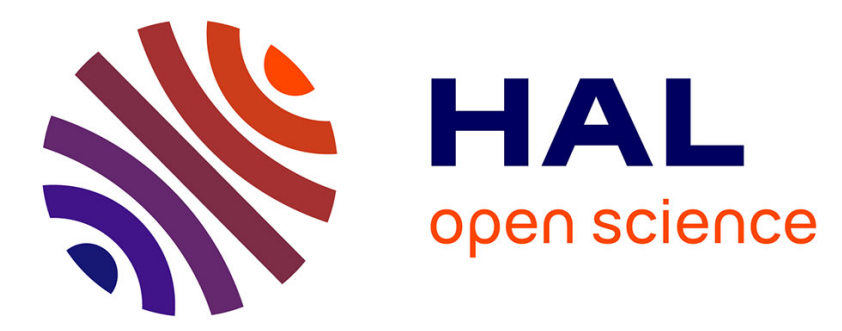

\title{
Long-term effect of water chemistry on the swelling pressure of a bentonite-based material
}

Qiong Wang, Yu-Jun Cui, Anh Minh A.M. Tang, Pierre Delage, Behrouz Gatmiri, Wei-Min Ye

\section{- To cite this version:}

Qiong Wang, Yu-Jun Cui, Anh Minh A.M. Tang, Pierre Delage, Behrouz Gatmiri, et al.. Long-term effect of water chemistry on the swelling pressure of a bentonite-based material. Applied Clay Science, 2014, 87, pp.157-162. 10.1016/j.clay.2013.10.025 . hal-00926946

\section{HAL Id: hal-00926946 \\ https://hal-enpc.archives-ouvertes.fr/hal-00926946}

Submitted on 23 Feb 2015

HAL is a multi-disciplinary open access archive for the deposit and dissemination of scientific research documents, whether they are published or not. The documents may come from teaching and research institutions in France or abroad, or from public or private research centers.
L'archive ouverte pluridisciplinaire HAL, est destinée au dépôt et à la diffusion de documents scientifiques de niveau recherche, publiés ou non, émanant des établissements d'enseignement et de recherche français ou étrangers, des laboratoires publics ou privés. 
2 Long-term effect of water chemistry on the swelling pressure of a bentonite-based material

4

5 Qiong Wang ${ }^{1}$, Yu-Jun Cui ${ }^{1,3}$, Anh Minh Tang ${ }^{1}$, Pierre Delage ${ }^{1}$, Behrouz Gatmiri ${ }^{2}$, Wei-Min

$6 Y e^{3}$

$7 \quad{ }^{I}$ Ecole des Ponts ParisTech, Laboratoire Navier/CERMES, 6-8 av. Blaise Pascale, Marne-la-Vallée, France

$8{ }^{2}$ ANDRA, France

$9 \quad{ }^{3}$ Tongji University

10

11

12

13

14

15

16

17 Corresponding author:

18 Prof. Yu-Jun CUI

19 Ecole des Ponts ParisTech

20 6-8 av. Blaise Pascal, Cité Descartes, Champs-sur-Marne

21 F-77455 MARNE LA VALLEE

22 France

23

24

Telephone: +33164153550

Fax: +33164153562

E-mail: yujun.cui@enpc.fr 
Abstract

29

47 Keywords: Radioactive waste disposal; bentonite based materials; pore water chemistry;

Compacted bentonite-based materials have been proposed as possible sealing andbackfill materials in geological repositories for the high-level radioactive waste disposal in several countries.During the long time lifespan of a repository, as the chemical composition of porewater can change, the swelling and sealing capacity of the material mayalso change.From a point of view of storage safety assessment, it is important to evaluate thispossible change of swelling capacity. In this study, a mixture of bentonite and crushedCallovo-Oxfordian claystone was investigated. The long-term effect of pore waterchemistry on the swelling pressure was studied at constant-volume conditions for 700days. Distilled water and synthetic water having the chemical composition similar tothat of in-situ pore water were used for hydration. The results obtained in an initial period of100 hours revealed no significant influence of the water composition on the swellingpressure evolution, and the maximum swelling pressures observed were close to4.30 MPa for a dry density of $1.70 \mathrm{Mg} / \mathrm{m}^{3}$. Over a longer time period, on the contrary, the swelling pressure eventually decreased for allsamples, especially for the sample saturated with synthetic water. In addition,comparison of a one-step soaking test with a multi-step soaking test showed nowetting procedure effect on the long term swelling behaviour. All the results areanalysed by considering the physico-chemical interaction between the minerals ofclaystone, minerals of bentonite and different fluids involved. time dependence; swelling pressure 
51 Compacted bentonite-based materials have been proposed as possible

52 sealing/backfillmaterials in deep geological repositories for high-level radioactive wastes

53 (HLW) inseveral countries. Due to their favourable swelling characteristics, these materials areexpected to fill up all voids left in the system after construction and emplacement of the waste packages. An important long-term safety function of bentonite-based barriers is to ensurea relatively impermeable zone around the high-level radioactive waste thereby limiting groundwater flow and waste package degradation rates and, ultimately, waste leaching rates. This roletermed as "sealing" (Komine, 2004; Komine and Ogata, 2003) is essential to ensurethe overall safety of the geological disposal: the disposed waste is isolated from thebiosphere over long time. For this purpose, the swelling property becomes a key factorin the design and fabrication of the sealing/backfill materials, and needs to be studiedin depth.

The swelling properties (i.e. swelling pressure or swelling potential) ofbentonite-based materials have been widely investigated (Pusch, 1982; Komine andOgata, 1994, 2003, 2004a; Delage et al., 1998; Agus and Schanz, 2005; Komine et al.,2009). They depend strongly on the initial state such as dry density and water content(Komine and Ogata, 1994; Villar and Lloret, 2008). After being installed in the field,especially in some geological host formations relatively rich in salts (e.g. saltformation, claystone, granite formations, etc.), site water of certain salinity caninteract with bentonite (Herbert et al., 2008); as a result, the hydromechanicalbehaviourof the bentonite-based materials and in turn the performance of the barrier maybe notably affected. Moreover, the water composition can change over time.

Frequently, bentonite/sand mixtures are considered for the reason of good control ofswelling pressure, enhanced thermal conductivity as compared to pure bentonite and a better mechanical resistance. Forinstance, a 70/30 bentonite-sand mixture was proposed as buffer 
material in Japanwhile a 50/50 bentonite/sand mixture was suggested in the Canadian repositoryconcept (Dixon et al., 1985). In France, Callovo-Oxfordian (COx) claystone has been considered as apossible geological host-rock for high-level radioactive waste disposal, and themixture of bentonite and crushed Callovo-Oxfordian (COx) claystone is proposed as apossible sealing/backfill material for environmental and economic reasons (Andra,2005; Tang et al., 2011a; Tang et al., 2011b; Wang et al., 2012). If physico-chemicalinteractions essentially take place only between groundwater and bentonite in the case ofsand/bentonite mixture, it is not the case for the bentonite/claystone because of the additional interactions between these two materials and the water. Due to the low permeability of thebentonite-based materials, these interactions might develop overlongtime and the resulting effects will not be immediate. Hence, particular attention should be paid to their long-term behaviour.

This study focuses on the swelling pressure of the compacted mixture of MX80bentonite and crushed COx claystone. The long term effect of water chemistry on theswelling pressure and microstructure were investigated after 700 days in contact with water.Emphasis was put on the physico-chemical interaction between the minerals ofclaystone, minerals of bentonite and different fluids involved. The wetting procedureeffect on the long term swelling behaviour was also investigated by comparing a one-step soaking test with multistep soaking test.

\section{MATERIALS AND METHODS}

\subsection{Materials}

The bentonite used in this study is a commercial MX80 Na-bentonite, which containslarge quantities of montmorillonite (75-90\%). Silt is the dominant remaining fraction, which mainly consists of quartz and feldspars as well as micas, sulphides, and oxides(Pusch 1982). Table 1 details the main mineralogical components of MX80 bentoniteobtained by several authors. 
97 The total cation exchange capacity (CEC) is between 0.78 and $0.85 \mathrm{meq} / \mathrm{g}$ (Table 2), the cation population at exchange positions is mainlycomposed of $\mathrm{Na}^{+}(60.0-67.0 \mathrm{meq} / 100 \mathrm{~g})$, other population being much lower: $\mathrm{Ca}^{2+}(5 \cdot 0-8.0 \mathrm{meq} / 100 \mathrm{~g}), \mathrm{Mg}^{2+}(3.0-4.0 \mathrm{meq} / 100 \mathrm{~g})$ and $\mathrm{K}^{+}(0.2-1.3 \mathrm{meq} / 100 \mathrm{~g})$. The grain size distribution (Fig.1) determined by hydrometer (AFNOR NF P94-057)shows that the fraction of clay-size particles $(<2 \mu \mathrm{m})$ is $84 \%$. The bentonite tested has anaverage specific gravity of 2.76 , a liquid limit of $520 \%$, and a plastic limit of $42 \%$.

Callovo-Oxfordian (COx) claystone was taken at 490-m depth from the UndergroundResearch Laboratory (URL) at Bure in eastern France. It contains 40-45\% clayminerals (mainly interstratified minerals of illite-smectite), 20-30\% carbonates(mainly calcite) and 20-30\% quartz and feldspar (Hoteit et al., 2000; Lebon andGhoreychi, 2000; Zhang et al., 2004). The in-situ water content is $2.8-8.7 \%$; the bulkdensity is $2.32-2.61$ $\mathrm{Mg} / \mathrm{m}^{3}$ and the specific gravity is 2.70 (Hoteit et al., 2000; Tanget al., 2011a). The excavated claystone was air-dried and crushed into a powder. Fig. 1 depicts thegrain size distribution of the crushed powder obtained by dry sieving; it contains $18 \%$ of fine grains $(0.08 \mathrm{~mm})$. The grain size distribution determined by hydrometerconfirms that the content of clay-size particles $(<2 \mu \mathrm{m})$ is $40 \%$.

Both distilled water and synthetic water were used for hydration. The chemicalcomposition of the synthetic water (see Table 3) is similar to that of the groundwaterat Bure site. The $\mathrm{pH}$ values are between 7.00 and 7.28; the concentration of $\mathrm{Na}+$ istwice that of $\mathrm{Ca}^{2+}$ and $\mathrm{Mg}^{2+}$ and four times that of $\mathrm{K}^{+}$(Gaucher et al., 2006; Marty etal., 2010).

\subsection{Sample preparation}

In this study,all tests were performed on samples of compacted bentonite/claystonemixture with a bentonite content of $70 \%$ in dry mass. Bentonite and claystonepowders, with the 
initial water contents of $11.8 \%$ and $2.64 \%$ respectively, were firstcarefully mixed prior to

122

123

124

compaction. Samples were statically compacted to a drydensity of $1.70 \mathrm{Mg} / \mathrm{m}^{3}$ in a metallic cell (70 $\mathrm{mm}$ in internal diameter) at a controlledrate of $0.05 \mathrm{~mm} / \mathrm{min}$. After compaction, the sample height is about $10 \mathrm{~mm}$. The total suction measured in these specimens using ahygrometer was $s=90 \mathrm{MPa}$. The specimensare then carefully introducedinto constantvolume cells (having the same diameter as the compaction cell) forthe swelling pressure experiment.

\subsection{Experimental methods and programme}

The constant-volume cell used in this study is presented in Fig.2. It consists ofthreeparts: (1) the bottom part containing a porous stone and a drainage system; (2) themiddle cell $(70 \mathrm{~mm}$ inner diameter, $10 \mathrm{~mm}$ height) used to prevent radial swelling,with two air outlets; (3) the top part incorporating a total pressure sensor (workingpressure of $5 \mathrm{MPa}$ ) to monitor the swelling pressure. The sample was wetted byconnecting the water inlet to a water reservoir or a suction control system usingvapour equilibrium technique at an ambient temperature of $20 \pm 1$ ${ }^{\circ}$ C. More details can be found in Tang et al. (2011b), Wanget al. (2012).

Four swelling pressure tests were performed using the constant-volume cell (Table 4).In tests LT01 and LT02 (LT stands for long term), the samples were saturated withsynthetic water and distilled water, respectively. The duration of these testscarried out to study the long-term effect of water chemistry on the swellingpressurewas 700 days. In test LT03, three decreasing suctions (57 MPa, 38 MPa and 12.6 MPa) were firstapplied in steps using vapour equilibrium technique, prior to distilled water floodingin the last stage. This test also lasted 700 days. This test was performed to investigate the effect of the wetting procedure on the long termswelling behaviourby comparisonwith test LT02. Test ST (ST for short term) was performed by directly injectingsynthetic water as in test LT01, but with a shorter duration of 100 hours. 
After certain hydration time (see Table 4), the specimen was taken out of the cell for the analysis of pore-size distributionby Mercury Intrusion Porosimetry (MIP).

\section{EXPERIMENTAL RESULTS}

Fig.3 presents the results from tests LT01, LT02, and ST during the first 100 hours afterthe injection of water. The three curves are very similar, showing negligible effect ofwater chemistry for this duration and also the good repeatability of the tests. Withwater infiltration, swelling pressure first increased very quickly; after about 20 hours theswelling pressure reached a first plateau at about $3.4 \mathrm{MPa}$. After 32 hours, the swellingpressure started to increase again and reached a second plateau after 100 hours. The finalvalues were in the range of $4.30-4.37 \mathrm{MPa}$ for the three tests.

The results of test LT03 are presented in Fig.4. The application of the first suction of $57 \mathrm{MPa}$ resulted in a swelling pressure of $0.57 \mathrm{MPa}$. Then, the second suction of $38 \mathrm{MPa}$ was applied and the swelling pressure reached 1.43 MPa. With the thirdsuction of $12.6 \mathrm{MPa}$ the swelling pressure increased to $2.61 \mathrm{MPa}$. The zero suctionapplied by direct contact with distilled water led the sample to a maximum value of $4.39 \mathrm{MPa}$ swellingpressure. This value is quite close to that from test LT02 (4.37 MPa) in which thesample was directly put in contact with distilled water. This indicates that the wettingprocedure did not affect the shortterm swelling behaviour for this material.

In Fig.5, all results from the three tests LT01, LT02 and LT03 during 700 days arepresented. It appears that over this long period, the swelling pressure decreased somewhat for allsamples, especially for the sample saturated with synthetic water (LT01). The finalswelling pressure was $3.95 \mathrm{MPa}$ (corresponding to a decrease of $9 \%$ ), and $4.19 \mathrm{MPa}($ decrease of $3 \%$ ) for 
samples saturated with synthetic water (LT01) and distilled water(LT02 and LT03), respectively.

169

170

171

The pore size distribution curve for all the samples taken at the end of the tests arepresented in Fig. 6. It is observed in Fig. 6a that the final values of intruded mercuryvoid ratio $\left(e_{m}=\right.$ intruded mercury volume over soil solid volume) are between 0.4 and0.5, much lower than the global void ratio $(e=0.61)$. This shows that a large amount ofporosity isinaccessible to mercury. Comparison between the curves obtained after different durations clearly shows that the amount of accessible porosity after 700 days is larger in both cases of distilled water (LT02 and LT03) and synthetic water (LT01) than after 100 hours with synthetic water. In addition, for samples hydrated for 700 days, more quantity of accessible porosity is observed in the case of synthetic water (LT01).

The incremental pore volume $\mathrm{d} e_{m} / \operatorname{dlog}(d)$ (Fig. 6b) refers to the volume of mercurythat intrudes into the pores between pressure increments. For all samples a typicalbimodal porosity can be observed; thus, two pore groups can be defined: a group ofmicro-pores having a mean size of $0.02 \mu \mathrm{m}$ and a group of macro- pores having amean size of $20 \mu \mathrm{m}$. After 700-day saturation (LT01, LT02 and LT03), themacro-pores and micro-pores quantity increased when comparing to the short-termtest (ST). Change in macro-pores is more significant especially for the samplesaturated with synthetic water (LT01). For tests LT02 and LT03 which were hydratedwith distilled water, very similar curves were observed suggesting no effect of thewetting procedure on the pore-size distributions. As far as changes in pores size are concerned,it can be observed that over time the group of micro-pores had a size slightlydecreased. On the contrary, the group of macro-pores had a size slightlyincreased. Changes for test LT01 weremore marked. 


\section{INTERPRETATION AND DISCUSSION}

191 Various studies showed that the swelling capacity of bentonite is lower in saline water;the

192 higher the dissolved salt concentration, the lower the swelling pressure. This

193 phenomenonbecomes less pronounced in case of high dry density (Studds et al., 1998;

194 Karland etal., 2005; Suzuki et al., 2005; Karland et al., 2006; Castellanos et al., 2008;

195 Katsumi etal., 2008; Siddique et al., 2011). In general, with a high void ratio (low dry

196 density)and/or high salt concentrations, the influence of pore water chemistry on

197 bentonitebehaviour is significant and can be qualitatively explained by the diffuse double layer(DDL) theory (Karland, 1997; Mata, 2003; Castellanos et al., 2008). For densebentonite, since there is little water present between adjacent clay platelets, there canbe little or no development of a DDL associated with the clay particles (Dixon, 2000;Pusch and Yong, 2006); thus it becomes difficult even impossible to describe thebentonite behaviour by the DDL theory.

In this regard, Karnland et al. (2005) studied the effect of salinity on theswelling pressure of MX-80 bentonite, and noted that the effect of salinity of thesaturating fluid was relatively lower with a higher density. For MX80 bentonite,Dixon (2000) also concluded that at an effective bentonite dry density (bentonite drydensity in the bentonite/sand mixture) higher than $1.22 \mathrm{Mg} / \mathrm{m}^{3}$, changes in waterchemistry do not significantly affect the swelling behaviour due to the small numberof water molecule layers between clay sheets. Confirmation was made by Castellanos et al.(2008) on the FEBEX bentonite: an increase in salt concentration reduced theswelling pressure, but this change was much less marked for high density. It can bededuced that for the studied bentonite/claystone mixture, the high density $\left(1.70 \mathrm{Mg} / \mathrm{m}^{3}\right)$ and the low salinity of the synthetic water (see Table 3) representative 
of the present in situ conditions resulted together in thenegligible effect of water chemistry on the swelling pressure in short term.

215 Basically, the swelling pressure of bentonite is mainly related to the crystallineswelling and double layer swelling. Crystalline swelling is caused by the hydration ofexchangeable cations $\left(\mathrm{K}^{+}, \mathrm{Na}^{+}, \mathrm{Ca}^{2+}, \mathrm{Mg}^{2+}\right)$ between mineral layers that have astructure with one alumina octahedral sheet sandwiched between two silica tetrahedralsheets. It is a process which involves the adsorption of a maximum number of hydratesdepending on the nature of cations. After three to four water monolayers, i.e. atinterlayer separation distances $\geq 1 \mathrm{~nm}$, the surface hydration becomes less significant andthe electrical double-layer repulsion becomes the main swelling mechanism (Bradburyand Baeyens, 2003; Suzuki et al., 2005). For clay at high density, the low amount ofwater taken up is to all intents and purposes pseudo-crystalline interlayer water, andinsufficient to form the DDL (Pusch and Yong, 2006). Therefore, the swellingpressure is mainly governed by the crystalline swelling (interaction between the layersurfaces and water) and the double layer repulsion makes only a limitedcontribution. In thiscase, the exchangeable cations are the key elements that control the clay-waterinteraction (Abdullah et al., 1997).

As far as the pore water is concerned, it may significantly affect the chemicalcompositions of clays through the exchangeable cations (Yukselen et al., 2008). Thecation exchange reaction is mainly controlled by the exchange capacity of the clayminerals (Mata, 2003); the ease with which a cation of one type can replace a cationof another type depends mainly on the valence, relative abundance of the differentcation types, and the cation size. Other factorsbeing equal, the higher the valence ofthe cation, the higher the replacing power; for cations of the same valence, thereplacing power increases with the size of the cation (Laine and Karttunen, 2010). 
2003). According to this order, for the Na-bentonite as in this study, ittends to change from sodium $\left(\mathrm{Na}^{-}\right)$to other types (i.e. $\mathrm{K}^{-}, \mathrm{Mg}^{-}$or $\mathrm{Ca}^{-}$) depending onthe cations present in the permeating water.

One of the most common cation exchange reactions in the Na-bentonite is the oneinvolving sodium and calcium (Mata, 2003). Mata (2003) investigated the evolutionof $\mathrm{Ca}^{2+}$ and $\mathrm{Na}^{+}$in a specimen of sodium MX80 bentonite hydrated with saline water $(\mathrm{NaCl}$ and $\mathrm{CaCl}, 50 / 50$ by mass) and distilled water. Analysis of the collected porefluid showed an increaseof sodium concentration and a decrease of calciumconcentration as compared to the injected water. This suggeststhat the sodium bentonitewas transformed to a calcium bentonite. Montes- $\mathrm{H}$. et al. $(2004,2005)$ investigatedthe chemical transformation of Na/Ca-MX80 bentonite (Na0.18Ca0.10) in arepresentative pore water $(\mathrm{pH}=7.3)$ from Bure site $(-180 \mathrm{~m})$, the $\mathrm{Na} / \mathrm{Ca}-$ to Camontmorillonite conversion was identified as the main chemical transformation. At aconstant temperature, this transformation is affected by the groundwater composition(pH and cation concentrations) and solid/liquid ratio as well as the reaction time(Mitchell, 1976; Herbert et al., 2004; Fernández and Villar, 2010; Laine and Karttunen,2010). For the short term swelling pressure test in this study, it was actually the lowcation concentration (low salinity of synthetic water mentioned above) and highsolid/liquid ratio (i.e. high density) that led to the negligible effect of water chemistryon the swelling pressure. Nevertheless, after a long time period of reactions, the effectbecame evident because the presence of $\mathrm{Ca}^{2+}$ in Bure site water (see Table 3) enabledpart of Na-montmorillonite to change to Ca-montmorillonite which has a much lowerexpansibility. This process resulted in a decrease of swelling pressure overtime asshown in Fig.5.

The transformation from sodium to calcium montmorillonite is critically dependent onthe amount of available calcium $\left(\mathrm{Ca}^{2+}\right)$ in the pore water (Muurinen and Lehikoinen,1999; 
261 Fernández et al., 2004, Fernández and Villar, 2010). Forthe sample saturatedwith distilled water, the pore water chemistry evolved over time to reachequilibrium with the claystone minerals (the claystone contains $20-30 \%$ carbonates, mainlycalcite).Consequently, it was as if diluted Bure site water infiltrated to the MX80bentonite, leading to the degradationof swelling pressure. However, with a much lower cationconcentration (only 30\% claystone in the mixture), the decrease of swellingpressure was less significant than in the casewith synthetic water.

For the sample first wetted by three steps of suction (LT03), after the sample wasflooded with distilled water, the maximum swelling pressure was found close to thatobtained by waterflooding the sample directly (LT02), indicting anegligible effectof wetting procedure on the swelling pressure (Figs. 3 and 4). This phenomenoncan be explained bythe mechanism identified by Cui et al. (2002): when hydrating bydecreasing suction (57-38-12.6 MPa) under confined conditions, the macro-pores wereprogressively cloggedby the invasion of exfoliated clay particles, whereas the micro-pores remained almost un-affected. Themicro-pores started to change only when the water saturation is approached. Thissuggests that step-wetting by suction control and direct flooding with water may leadto similar microstructures after saturation, thus similar maximum swelling pressures.After 700-day hydration with distilled water, not only similar swelling pressures (Fig.5), but also similar pore-size distributions were observed for tests L02 and L03 (Fig.6), which enhanced this conclusion. In addition, the repeatability of swelling pressure testand the MIP test was verified.

It was noted that the chemical effect on the HM behaviour of clayey soils is due tochanges at different structural levels and the interaction between them (Mata 2003).From the pore-size distribution observation in this study, it can be seen that the amount ofaccessible porosity increased after a long time period for both distilled (LT02 andLT03) and synthetic water 
285 (LT01), with more increase for synthetic water (Fig. 6). Ifwe relate these phenomena to the 286 swelling pressure, it is clear that the sample withlower swelling pressure had a higher

287 intruded mercury void ratio in both micro- andmacro-pores. For samples with higher swelling 288 capacity, more interlayer hydrationoccurred, leading to a constriction of accessible pores. 289 When referring to theincremental pore volume, the same tendency can be identified, for the 290 sample withhigher swelling pressure, both the macro-pores and micro-pores decreased. 291 However,most of changes in microstructure occurred in macro-pores family. The 292 sameobservation can be made in terms of pore size changes. This is in agreement with 293 theobservation made by Mata (2003) who conducted MIP test on the compacted 294 sodiumbentonite MX80 and sand mixture (70/30) (dry density of 1.37 and 1.67 $295 \mathrm{Mg} / \mathrm{m}^{3}$ )saturated with distilled water and saline water, and found that the saline water 296 effectswere significant on the macro-pores, the micro-pores remaining almost unaffected.

\section{CONCLUSION}

298 Long term swelling pressure tests and MIP tests on a bentonite/claystone mixturewere performed. The effects of water chemistry as well as the hydration procedure onthe swelling pressure were investigated in both short andlong terms. The results areanalysed by considering the physico-chemical interaction between the minerals ofclaystone, the minerals of bentonite and the different pore water chemistries involved.

There was no obvious effect of water chemistry on the swelling pressure in short term(100 hours) due to the high dry density of the bentonite-based material and the low salinity of the synthetic water. However, aftera long period of 700 days, the swelling pressure decreased for all samples, especiallyfor the sample saturated with synthetic water. 
Different hydration procedures led to comparable long term swelling behaviour and similarpore-size distributions.

309

310

311

The effect of the chemical composition of the pore water on the swelling pressure can be interpreted in terms of changes inmicrostructure. The sample with higher swelling pressure showed less macro andmicro-pores associated with a higher interlayer hydration.

From a practical point of view, the specification and the design of the sealing/backfillmaterial are often made based on the swelling properties measured in short term.However, a nonnegligible decrease (9\%) of swelling pressure was observed after 700days even with a water of low salinity. This expected reduction of swelling pressure has thus to be taken into account when designing a repository to ensure that the bentonite-based barrier will also meet the requirements on which its long term performance rests.Considering the possible pore water chemical composition changes over the very long term lifespan of the repository is also recommended to avoiddeterioration of the swelling capacity of these materials and thus of the self-sealing capacity of the system.

\section{Acknowledgements}

The support from the PHC Cai Yuanpei project (24077QE) and that of the ChinaScholarship Council (CSC) are greatly acknowledged.

\section{References}

Abdullah, W.S., Al-Zou'bi, M.S., Alshibli, K.A., 1997. On the physicochemical aspects of compacted clay compressibility. Can. Geotech. J, Vol 34, 551-559.

AFNOR, 1992. AFNOR NF P94-057, Soils: investingation and testing. Granulometric analysis. Hydrometer method. Association Francaise de Normalisation. France.

Agus, S., Schanz, T., 2005. Swelling pressures and wetting-drying curves of a highly compacted bentonite-sand mixture. Unsaturated Soils: Experimental Studies, pages 241-256. 
Andra, 2005. Référentiel des matériaux d'un stockage de déchets à haute activité et à vie longue Tome 4: Les matériaux à base d'argilites excavées et remaniées. Rapport Andra $\mathrm{N}^{\circ}$ CRPASCM040015B.

Bradbury, M.H., Baeyens, B., 2003. Porewater chemistry in compacted re-saturated MX-80 bentonite. Journal of Contaminant Hydrology, 61,329-338

Castellanos, E., Villar, M.V., Romero, E., Lloret, A., Gens, A., 2008. Chemical impact on the hydromechanical behaviour of high-density febex bentonite. Physics and Chemistry of the Earth, Parts A/B/C, 33(Supplement 1):S516 - S526.

Cui, Y. J., Loiseau, C., Delage, P., 2002. Microstructure changes of a confined swelling soil due to suction controlled hydration Unsaturated soils: proceedings of the Third International Conference on Unsaturated Soils, UNSAT 2002, 10-13 March 2002, Recife, Brazil, 593.

Dixon, D. A.. Gray, M. N. and Thomas, A. W. 1985. A study of the compaction properties of pot ential clay-sand buffer mixtures for use in nuclear fuel waste disposal, Engineering Geology, 21 , $247-255$

Delage, P., Howat, M. D. \& Cui, Y. J., 1998. The relationship between suction and swelling properties in a heavily compacted unsaturated clay. Engineering Geology 50, 31-48.

Dixon, D.A., 2000. Porewater salinity and the development of swelling pressure in bentonite-based buffer and backfill materials. POSIVA Report 2000-04, Posiva Oy, Helsinki, Finland.

Fernández, A..M., Baeyens, B., Bradbury, M., Rivas, P., 2004. Analysis of the porewater chemical composition of a Spanish compacted bentonite used in anengineered barrier. Phys. Chem. Earth 29, 105-118.

Fernández, A.M., Villar, M.V., 2010. Geochemical behaviour of a bentonite barrier in the laboratory after up to 8 years of heating and hydration. Applied Geochemistry 25, 809-824

Gaucher E. C., Blanc P., Bardot F., Braibant G., Buschaert S., Crouzet C., Gautier A., Girard J.-P., Jacquot E., Lassin A., Negrel G., Tournassat C., Vinsot A., and Altmann S. 2006. Modelling the porewater chemistry of the Callovian-Oxfordian formation at a regional scale. Comptes Rendus Geosciences 338(12-13), 917-930.

Herbert, H.-J., Kasbohm, J., Moog, H.C. \& Henning, K.-H. 2004. Long-term behaviourof the Wyoming bentonite MX-80 in high saline solutions. Applied Clay Science, 26,275-291.

Herbert, H.-J., Kasbohm, J., Sprenger, H., Fernández, A.M. \& Reichelt, C. 2008.Swelling pressures of MX-80 bentonite in solutions of different ionic strength. Physicsand chemistry of the earth, 33, 327-342.

Hoteit, N., Ozanam, O., Su, K., 2000. Geological Radioactive Waste Disposal Project in France: Conceptual Model of a Deep Geological Formation and Underground Research Laboratory in Meuse/Haute-Marne Site. The 4th North American Rock Mechanics Symposium, Seattle, July 31-August 3, 2000.

Karnland, O., 1997. Bentonite swelling pressure in strong $\mathrm{NaCl}$ solutions. Correlationbetween model calculations and experimentally determined data. SKB Technical Report 97-31. Swedish Nuclear Fuel and Waste Management Co., Stockholm, pp. 1-30.

Karnland, O., Muurinen, A., Karlsson, F., 2005. Bentonite swelling pressure in $\mathrm{NaCl}$ solutionsExperimentally determined data and model calculations. Advances in Understanding Engineering Clay Barriers. Page 241.

Karnland, O., Olsson, S. \& Nilsson, U. 2006. Mineralogy and sealing properties of various bentonites and smectite-rich clay materials. SKB TR-06-30. Swedish Nuclear Fuel and Waste Management Co, Stockholm, Sweden. 
Katsumia, T., Ishimorib, H., Onikatac, M., Fukagawab,R., 2008. Long-term barrier performance of modified bentonite materials against sodium and calcium permeant solutions Geotextiles and Geomembranes 26,14-30.

Komine., H., Ogata, N. 1994. Experimental study on swelling characteristics of compacted bentonite. Canadian geotechnical journal, 31(4):478-490.

Komine., H., Ogata, N. 2003. New equations for swelling characteristics of bentonite-based buffer materials. Canadian Geotechnical Journal, 40(2):460-475.

Komine, H., 2004. Simplified evaluation for swelling characteristics of bentonites, Engineering geology, 71(3-4): 265-279.

Komine, H. Yasuhara, K. and Murakami, S. 2009. Swelling characteristics of bentonites in artificial seawater. Canadian Geotechnical Journal, 46(2):177-189.

Laine H. , Karttunen P.,2010 . Long-Term Stability of Bentonite A Literature Review. POSIVA Report 2010-53, Posiva Oy, Helsinki, Finland.

Lebon P, Ghoreychi M. French underground research laboratory of Meuse/Haute-Marne: THM aspects of argillite formation. In: EUROCK2000 Symposium. Aachen: [s. n.], 2000: 27-31.

Marty, N., Fritz, B., Clément, A., Michau, N., 2010, Modelling the long term alteration of the engineered bentonite barrier in an underground radioactive waste repository, Applied Clay Science 47 (2010) 82-90

Mata, C., 2003. Hydraulic behaviour of bentonite based mixtures in engineered barriers: The Backfill and Plug Test at the A" spo" HRL (Sweden). Ph. D. Thesis. Universitat Polite`cnica de Catalunya. 257 pp. Barcelona.

Mitchell, J.K., 1976. Fundamentals of Soil Behavior, John Wiley \& Sons, New York.

Montes-H, G., Geraud, Y., 2004. Sorption kinetic of water vapour of MX80 bentonite submitted to different physical-chemical and mechanical conditions. Colloids and Surfaces A: Physicochemical Engineering Aspects 235, 17-23.

Montes-H, G., Geraud, Y., Duplay, J. \& Reuschlé, 2005. ESEM observations of compacted bentonite submitted to hydration/dehydration conditions. Colloids and surfaces A: Physicochem. Eng. Aspects, 262, 14-22.

Muurinen, A., Lehikoinen, J.,1999, Porewater chemistry in compacted bentonite, Engineering Geology 54 (1999) 207-214

Pusch, R., 1982. Mineral-water interactions and their influence on the physical behavior of highly compacted Na bentonite. Canadian Geotechnical Journal, 19(3):381-387.

Pusch, R., 2001. Experimental study of the effect of high porewater salinity on the physical properties of a natural smectitic clay, SKBF/KBS technical report. No.TR01-07.

Pusch, R., Yong, R.N., 2006,Microstructure of Smectite Clays and Engineering Performance, Taylor\& Francis, London and New York.

Siddiqua, S., Blatz, J., Siemens, G., 2011, Evaluation of the impact of pore fluid chemistry on the hydromechanical behaviour of clay-based sealing materials, Can. Geotech. J. 48: 199-213.

Studds, P.G., Stewart, D.I., and Cousens, T.W. 1998. The effects of salt solutions on the properties of bentonite-sand mixtures. Clay Minerals, 33: 651-660.

Suzuki, S.; Prayongphan, S.; Ichikawa, Y. \& Chae, B. 2005. In situ observations of the swelling of bentonite aggregates in $\mathrm{NaCl}$ solution, Applied Clay Science, Elsevier, 29: 89-98.

Tang, C.S., Tang, A.M., Cui, Y.J., Delage, P., Barnichon, J.D., Shi, B., 2011a. A study of the hydromechanical behaviour of compacted crushed argillite. Engineering Geology.118 (3-4):93-103. 
Tang, C.S., Tang, A.M., Cui, Y.J., Delage, P., Schroeder, C., De Laure, E., 2011b. Investigating the swelling pressure of compacted crushed Callovo-Oxfordian argillite. Physics and Chemistry of the Earth(special issue), Volume 36, Issues 17-18, 1857-1866

423

Villar, M.V., Lloret, A., 2008. Influence of dry density and water content on the swelling of a compacted bentonite. Applied Clay Science, 39(1-2):38-49.

Wang Q., Tang A. M., Cui Y.J., Delage P., Gatmiri, B., 2012 Experimental study on the swelling behaviour of bentonite/claystone mixture, Engineering Geology 124, 59-66.

427 Yukselen-Aksoy, Y., Kaya, A., Ören, A.H., 2008, Seawater effect on consistency limits and compressibility characteristics of clays, Engineering Geology 102 (2008) 54-61

Zhang, C., and Rothfuchs, T., 2004. Experimental study of the hydro-mechanical behaviour of the Callovo-Oxfordian argillite. Applied Clay Science, 26(1-4):325-336. 
$435 \quad$ List of Tables

436 Table 1. Mineral composition of the MX80 bentontie (\%)

437 Table 2. Exchangeable cations of MX80 bentonite (meq/100g)

438 Table 3. Chemical composition of the synthetic water

439 Table 4. Test programme

440

\section{$441 \quad$ List of Figures}

442 Figure 1. Grain size distribution curves of MX80 bentonite and crushed COx claystone

443 Figure 2. Constant-volume cell for swelling pressure measurement

444 Figure 3. Evolution of swelling pressure for tests LT01, LT02 and ST during the first $100 \mathrm{~h}$

445 Figure 4. Evolution of swelling pressure for samples wetted with decreasing suction

446 Figure 5. Evolution of swelling pressure for tests LT01, LT02, and LT03 for 700 days; (a) scale from 0 447 to $5 \mathrm{MPa}$, (b) scale from 3.6 to $4.6 \mathrm{MPa}$

448 Figure 6. Pore size distribution curves; (a) cumulative curves, (b) derived curves 